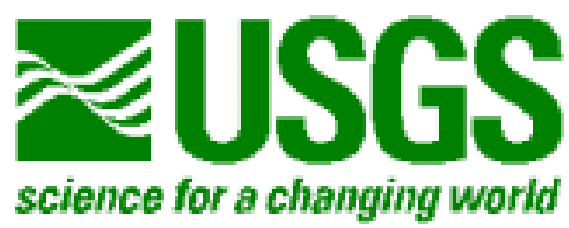

\title{
GEOCHEMICAL DATA FOR HISTORIC MINING AREAS, CENTRAL WESTERN SLOPE, COLORADO
}

By

\author{
J. Thomas Nash ${ }^{1}$, Warren C. Day ${ }^{2}$ and Anna B. Wilson ${ }^{3}$
}

Open-File Report 01-003

2001

This report can be downloaded from the Central Region website:

http://greenwood.cr.usgs.gov/pub/open-file-reports/ofr-01-0003

This report is preliminary and has not been reviewed for conformity with U. S. Geological Survey editorial standards or with North American Stratigraphic code. Any use of trade, product or firm names is for descriptive purposes only and does not imply endorsement by the U.S. Government.

\section{U. S. Department of the Interior U. S. Geological Survey}

\footnotetext{
${ }^{1}$ Box 25046 MS 973, Denver CO 80225; tnash@usgs. gov

2 Box 25046 MS 905, Denver CO 80225; wdayeusgs.gov

${ }^{3}$ Box 25046, MS 905, Denver, CO 80225; awilson@usgs.gov
} 


\section{TABLE OF CONTENTS}

Introduction 3

Field Methods 3

Water sampling and analysis $\quad 4$

Sampling and analysis of mineralized rocks 6

$\begin{array}{ll}\text { Data Files } & 7\end{array}$

$\begin{array}{lr}\text { Quality control for water analyses } & 8\end{array}$

$\begin{array}{ll}\text { References cited } & 11\end{array}$

List of figures and tables

$\begin{array}{ll}\text { Figure 1: Diagram of analytical error } & 10\end{array}$

Table 1: Elements determined in water and leachate solutions by ICP-MS 5 


\section{INTRODUCTION}

This report contains the analytical results for samples collected at 451 sites on the Central Western Slope of Colorado, including the Gunnison and Uncompahgre National Forests and adjacent public lands administered by the Bureau of Land Management. Included are results for 190 samples of surface waters, 185 samples of mined rocks, mill tailings, and altered rocks, and passive leach analyses of 116 samples of those mineralized materials, and 65 samples of host rocks. These geochemical analyses are part of studies designed to improve the understanding of known ore deposit types and to characterize the geochemical signature of historic mines and their host rocks and to determine their actual or potential contamination of surface or ground waters. Seventeen districts with significant historic mining activity were examined and sampled, but no active mines were investigated.

One focus of these reconnaissance geochemical studies was on materials and processes that are actively contributing, or have the potential to contribute acid or metals to surface waters. Water samples were collected wherever possible from springs, mine adits, streams, mine pits or puddles, and where there was no accessible water (ground water was not sampled) solid materials were collected and tested in the laboratory, using a passive leach test, for their potential to release acid and metals. Although the results for many metals of concern are reported to levels below 1 part per billion, the focus of this study is on the high concentrations that span four to six orders of magnitude for toxic metals such as $\mathrm{Cu}$ and $\mathrm{Zn}$. This investigation is concerned with geochemical processes that create those very high metal concentrations, and the geologic processes that attenuate acidity and high metal concentrations. The analytical methods used are appropriate for determination of many metals of potential concern and expected to have a wide range in concentration, and the ICP-MS method in particular is good for trace metals in water such as $\mathrm{As}, \mathrm{Cu}, \mathrm{Pb}$, and $\mathrm{Zn}$. (Crock and others, 1999). A secondary goal of the hydrogeochemical studies is screening of mining sites of interest to Federal land managers. If water compositions reported here suggest a problem source of contamination, follow-up work should be done using trace-metal sampling protocols and more precise analytical methods appropriate for water quality definition.

Acknowledgements. This study has benefited in many ways from helpful suggestions from staff of the BLM and USFS in Colorado, in particular Barbara Hite (BLM) and Daryl Gusey (USFS). Our colleagues in the USGS have offered helpful advice, comments on manuscripts, and chemical analyses; We thank in particular Paul Briggs, Jim Crock, Bob Eppinger, David Fey, Harley King, Al Meier, Bill Miller, and Brad van Gosen.

\section{FIELD METHODS}

Field studies were conducted from 1997 to 1999, typically in July and August when there was sufficient surface water for sampling. Sites visited and sampled were

determined by reference to published information, U.S. Geological Survey records in the Mineral Resources Data System (MRDS), information on U.S. Geological Survey 
1:24,000 scale topographic maps, and by accessibility. Sample localities were recorded on the topographic maps and measured with a conventional GPS (global positioning system) instrument having an accuracy of about \pm 100 to 150 feet (horizontal) based on tests at known sites. Sample locations are reported here in decimal degrees of latitude and longitude.

A six to eight digit identifier was assigned to each site or sample; an example is NGD201. Nash uses a system in which the first two characters, NG, designate the sampler (Nash) and study area. The third or fourth character designates the sample media or site type, most commonly $\mathrm{D}$, mine waste dump rocks; $\mathrm{R}$, altered (unmined) rocks; $\mathrm{W}$, water (of several types); L, leachate derived from a lab test. Other types are explained in the data tables. Field numbers assigned by Day indicate the sampler (WD, Warren Day; AW by Anna Wilson), the year, and a unique number for the site and sample.

\section{Water sampling and analysis}

The focus of these geochemical studies was the composition of surface waters spatially related to areas where mining has occurred, known mineralized and altered areas, as well as background sites not related to mineralization. Analyses of surface waters provide a quantitative measure of what contaminants are mobile in the vicinity of mines and available to wildlife and humans. Water samples were collected from mines and streams when the water was deemed to be representative of a geologic or mine setting and would yield information on the mobility of metals in that environment. The sampling methods have been used by the senior author since 1994 for reconnaissance characterization of geologic units, rock alteration, mine drainage, and reactions with tailings or dump materials (Nash and others, 1996); these methods are similar to but simplified from those described by Ficklin and Mosier (1999). Flow rate and water characteristics (color, suspended material, bed colors or mineralogy) are recorded, and $\mathrm{pH}$ and conductivity are measured using portable instruments. A pocket-sized conductivity meter (Corning CD-55) was used, which has an upper limit of 2,000 $\mu \mathrm{S} / \mathrm{cm}$. This device responded consistently and showed no drift after calibration. The $\mathrm{pH}$ meter (Orion 250), with built in temperature electrode, required frequent calibration throughout the day, and at most sites the calibration was checked on a standard solution after the field measurement. The field standards were buffered solutions of $\mathrm{pH} 4.0,7.0$, and 10.0. The $\mathrm{pH}$ measurements are thought to have an uncertainty of about \pm 0.05 standard units, even though the meter reports to 0.01 units, due to instrument drift, which is possibly larger than normal in the analysis of widely divergent compositions. A representative water sample for analysis was collected with a disposable $60 \mathrm{ml}$ syringe and then filtered using a disposable 0.45 -micron cellulose filter. The syringe and the 60 or $120 \mathrm{ml}$ polyethylene bottle were rinsed twice in the sampled water prior to collection. The filtered sample was acidified to a $\mathrm{pH}$ of about 2 at the site with 5 drops of ultrapure 1:1 $\mathrm{HNO}_{3}$ per $60 \mathrm{ml}$. At appropriate localities (with $\mathrm{pH}>4$ ) an unfiltered sample was collected for determination of alkalinity. Lab and field blank tests using deionized water indicated that contamination introduced by the sampling procedure and equipment is in the low parts per billion level (1-10 ppb), which we consider adequately low in our search for metal concentrations that are orders of magnitude greater than the sampling error. 
Each group of analyzed water samples included standard solutions and replicate samples (blind to the analyst); quality control is described in other reports (Lamothe and others, 1999; Fey and others, 2000).

Water samples were analyzed by several methods for various constituents using methods described by Briggs and Meier (1999), Lamothe and others (1999) and by Crock and others (1999). Concentrations of 40 to 60 elements (cations) were determined by inductively coupled plasma-mass spectrometry (ICP-MS) by a commercial laboratory (1996 to 1998 samples) and by the USGS (1999 samples). The elements and the lower limit of determinations are listed in table 1. Analytical results are in files GWC.xls and GWC99.xls.

Table 1: Elements determined in water and leachate solutions by ICP-MS, and their lower limits of determination

[Elements are listed by atomic weight; lower limit is in parts per billion; the limits shown are generalized and somewhat higher than stated by the commercial lab; limits in USGS analyses are similar].

$\begin{array}{llll}\mathrm{Li} & 0.1 & \mathrm{Nb} & 0.01 \\ \mathrm{Be} & 0.5 & \mathrm{Mo} & 0.04 \\ \mathrm{Na} & 0.8 & \mathrm{Ag} & 0.01 \\ \mathrm{Mg} & 0.5 & \mathrm{Cd} & 0.01 \\ \mathrm{Al} & 0.4 & \mathrm{Sn} & 0.01 \\ \mathrm{Si} & 1 & \mathrm{Sb} & 0.04 \\ \mathrm{~K} & 1 & \mathrm{Te} & 0.2 \\ \mathrm{Ca} & 1 & \mathrm{Cs} & 0.01 \\ \mathrm{Sc} & 0.1 & \mathrm{Ba} & 0.01 \\ \mathrm{Ti} & 0.04 & \mathrm{La} & 0.01 \\ \mathrm{~V} & 0.04 & \mathrm{Ce} & 0.01 \\ \mathrm{Cr} & 0.04 & \mathrm{Eu} & 0.01 \\ \mathrm{Mn} & 0.04 & \mathrm{Yb} & 0.01 \\ \mathrm{Fe} & 0.3 & \mathrm{Ta} & 0.01 \\ \mathrm{Co} & 0.01 & \mathrm{~W} & 0.01 \\ \mathrm{Ni} & 0.01 & \mathrm{Re} & 0.01 \\ \mathrm{Cu} & 0.01 & \mathrm{Os} & 0.01 \\ \mathrm{Zn} & 0.01 & \mathrm{Pt} & 0.01 \\ \mathrm{Ga} & 0.01 & \mathrm{Au} & 0.01 \\ \mathrm{As} & 0.04 & \mathrm{Tl} & 0.01 \\ \mathrm{Se} & 0.04 & \mathrm{~Pb} & 0.02 \\ \mathrm{Br} & 1 & \mathrm{Bi} & 0.01 \\ \mathrm{Rb} & 0.01 & \mathrm{Th} & 0.01 \\ \mathrm{Sr} & 0.01 & \mathrm{U} & 0.01 \\ \mathrm{Y} & 0.01 & & \end{array}$




\section{Sampling and analysis of mineralized and unmineralized rocks}

Rock chemistry. Mineralized rock samples were collected from mine dumps, outcrops, and mill tailings impoundments. In most cases the intent was to collect a representative sample, but for some sites a select sample was collected to determine a special property. The most commonly employed sampling method for dumps and tailings involved the collection of numerous small portions at 20 to 30 sub-sites, and sieving the materials through a $2 \mathrm{~mm}$ stainless steel sieve to derive a composite sample weighing about 2 to 4 pounds; this is the standard protocol developed for USGS-AML investigations (Nash, 1999). Mine dump samples collected by Day and Wilson (file GOR-ICP.xls) are the best exposed material available and are thought to be representative of the ore material of the associated mineral deposit. In most cases, the analyses represent composite samples of ore samples.

A suite of unmineralized rocks was collected by Day and Wilson to better understand the geologic setting as well as genesis of rock units that host ore deposits. These geochemical studies were part of a mineral resource assessment of the central Western Slope of Colorado and are presented in files GRX-MAJ.xls, GRX-ICP.xls, and GRX-INAA.xls.

Rock samples collected by Nash were pulverized at the USGS lab in Denver and analyzed by commercial laboratories. In one method the rocks are dissolved in a mixture of four acids, then the concentrations of 35 major and trace elements are determined using inductively coupled plasma (ICP); this is considered a total analysis as the strong acids dissolve all but the most refractory minerals such as zircon. This method is essentially that of Briggs (1996), although slight differences may exist between laboratories. Rock samples were also analyzed by a method that employs weaker acids to dissolve most minerals, then employs an organic reagent to collect 10 or 15 metals of interest (Ag, As, Au, Bi, Cd, Co, Cu, Hg, Mo, Pb, Sb, Se, Te, Tl, and Zn); analysis is by ICP; results are very similar to those of Motooka (1990) but one laboratory includes 5 additional elements. This second analytical method has lower levels of determination and works well for some elements, such as Sb, Se, Te, and Tl, that are not effectively determined by the total digestion method. Quality assurance monitoring shows that the precision and accuracy (deviation of the reported values from correct ones) is less than 5 percent for most elements. Analytical results of chemical analyses of solid materials are in a spreadsheet file GMR.xls that is included with this report.

Rock samples collected by Day and Wilson were analyzed by methods appropriate for the fresh or mineralized rocks. A set of 35 samples of mineralized rock samples, many from mine dumps, were analyzed by XRAL Laboratories, Toronto, Canada by ICP-AES using the method of Briggs (1996). Sulfur was determined by combustion and infrared analysis (Curry, 1996). Gold was determined by fire assay. A suite of 65 rock samples collected to determine the lithogeochemistry of rock units hosting ore deposits were analyzed by X-ray fluorescence spectroscopy by J. Taggart of the USGS for major elements (Mee and others, 1996), by ICP-AES (Briggs, 1996), and by ICP-AES for trace metals (Briggs and Meier, 199) and fire assay for gold by XRAL 
Laboratories, Toronto, Ontario, Canada. The rock samples were also analyzed by instrumental neutron activation analyses by R. Knight of the USGS using techniques of Wandless, (1996.)

Leachate chemistry. The chemical analyses just described are not always appropriate for environmental characterization because they describe total metal rather than mobile (soluble) metal concentrations. To determine the mobility of metals, as well as the tendency of a material to generate acid, a passive leach test (Nash, 1999; Fey and others, 2000) was utilized. Solid materials from dumps, mill tailings, and outcrops have been processed in the lab by a leach method that provides a measure of reactions in nature, such as during weathering or storm events. In this technique, $100 \mathrm{~g}$. of rock sample is sieved to $<2 \mathrm{~mm}$, placed in a beaker with $2,000 \mathrm{ml}$ of deionized water, stirred slightly, and the initial $\mathrm{pH}$ is measured. After about 20 hours, the upper part of the solution is stirred gently to mix the leachate solution. At 24 hours the $\mathrm{pH}$ and conductivity of the leachate is measured, and a $60 \mathrm{ml}$ aliquot is taken with a syringe and filtered through a 0.45 micron filter. The sample is acidified with 5 drops of ultrapure $1: 1 \mathrm{HNO}_{3}$. The leachate is analyzed by the same ICP-MS method used for water samples. Anions are not determined by ICP-MS and no work has been done on them in this investigation because the dominant anion in acidic solutions is expected to be sulfate. The analytical results (file GLC.xls) resemble those for surface waters degraded by mine waste (file GWC.xls). However, unlike the water analyses that show the results of real water-rock interactions, the leachate results show the potential to generate those compositions-actual behavior is more complex and involves factors such as permeability, kinetics, and climate, slope and aspect.

For most rock samples no sample preparation was done for these tests. The majority of dump samples were sieved to pass $2 \mathrm{~mm}$ while in the field. Mill tailings are by their nature ground to fine sand size and were not sieved. Unmined altered rock samples were crushed but not sieved. In a few instances, efflorescent crusts on dump or tailing materials were hand picked in the field or lab to provide material for leaching that is more than 50 percent crust. The samples were dry and friable when placed in the reaction vessel.

\section{DATA FILES}

Included in this report are 9 data files in spreadsheet format (xls as from Microsoft Excel) containing descriptive information on sites that were sampled and analytical results. The files are also provided in comma delimited format (cvs). The analytical results are mostly as reported by the chemists, except that some files have been simplified by deleting elements that are not obviously of high interest and have concentrations generally below the detection limit (such as ICP-MS results for more than ten rare earth elements) or for which analytical results are deemed unreliable or inappropriate (such as Hg by ICP-MS or Ag by one ICP-MS lab). Note that the spreadsheet files contain more figures than are significant. The files include:

NSAMD.xls: Description and location of 351 analyzed samples (Nash) 
NGMR.xls: Analytical results for 150 samples of mineralized materials

NGLC.xls: Analytical results for 116 leachate solutions from mineralized materials

NGWC.xls: ICP-MS analyses of 160 surface water samples collected in 1997 and 1998

NGWC99.xls: ICP-MS analyses of 30 surface water samples collected in 1999

GRX-maj.xls: XRF analyses of 65 unmineralized rock samples for major oxide abundances

GRX-inaa.xls: INAA analyses of 65 unmineralized rock samples for trace element abundances

GRX-icms.xls: ICP-AES and ICP-MS analyses of 65 unmineralized rock samples for trace elements and gold

GOR-icp.xls: ICP-AES analyses of 35 mineralized samples, including gold analyses by fire assay and sulfur by combustion analysis

\section{QUALITY CONTROL FOR WATER ANALYSES}

Standards and replicate samples were routinely submitted with field samples through the course of these studies. Approximately 5 percent of the analyzed samples were standards and replicates. A detailed accounting of quality control is beyond the scope of this report. Readers desiring such information should consult Lamothe and others (1999) for the performance of the USGS ICP-MS system. The commercial lab used for the 1997-1998 analyses reported here are similar. Quality control information for the ICP-MS analyses in 1997 and 1998 are presented elsewhere (Fey and others, 2000; Nash, 2000). Analytical performance differs for various elements, as mentioned below. The following trends are evident:

1. Results are reported for four to six orders of magnitude for most elements of interest in these natural waters and leachates, from less than $0.1 \mathrm{ppb}$ (part per billion or microgram per liter) to 100,000 or more than $1,000,000 \mathrm{ppb}$ in some unusual waters. This is a difficult challenge for any method or chemist. These samples often required dilution by amounts of 1:10 to 1:100 to keep the analyte within the calibration range.

2. Precision and accuracy are complex issues and are not the same for all elements and all concentration levels. We assume that analytical error is greater at the very high concentration levels of some of the unusual mine waters because there are no standards at this level, but documentation of that error is difficult and is incomplete at this date. Replicate samples suggest that precision at very high concentration levels is not much worse than at normal concentrations. Because reliable standards do not exist for waters 
with very high "trace" metal concentrations (>10,000 ppb), it is not possible to evaluate accuracy at high levels the way it is done at more normal levels. For reasons that we can not explain, the precision and accuracy for "major" elements ( $\mathrm{Al}, \mathrm{Ca}, \mathrm{Mg}$, etc) by this method are much lower than for trace metals. The user of these results should consider them semi-quantitative with errors of about 50 percent in some cases (but less in others). Another method, ICP-AES, provides more reliable results for major elements (Crock and others, 1999).

3. Based on standards and replicate samples, the precision for trace metals (such as As, $\mathrm{Cd}, \mathrm{Co}, \mathrm{Cr}, \mathrm{Cu}, \mathrm{Mn}, \mathrm{Mo}, \mathrm{Ni}, \mathrm{Pb}, \mathrm{Sb}, \mathrm{Se}, \mathrm{V}$, and $\mathrm{Zn}$ ) appears to be about 10 percent (1 standard deviation) for normal water concentrations, and possibly 20 percent at very high concentrations. The accuracy of determinations on these trace metals seems to be about 10 percent for normal concentrations. The precision and accuracy for Fe, which generally is not a trace metal in these waters, is not as good as for most metals, and possibly is about 20 percent.

4. Some trace metals pose special problems. Mercury is analyzed, but the $\mathrm{Hg}$ is not stable unless preserved by special methods (Crock, 1996), thus for water samples the $\mathrm{Hg}$ originally present was not present in the analyte (the analysis is valid, but the sample is not). Silver, a potentially toxic trace metal, should be high in many of the water samples, but analytical results for 1996-97 samples are very low and are not considered reliable. Results for Se, Te, and Tl appear to be reasonable but no standards contained these elements; precision is about the same as for other trace elements

5. These ICP-MS results are deemed satisfactory for the objectives of this study, the classification or ranking of water compositions. This sampling and analysis protocol has been used for five years in Arizona, Nevada, and Colorado AML studies and appears to be reproducible from day to day, year to year, at a total error of about 20 percent for most trace elements. Replicate analyses show that the composition of these acidified water samples change by less than a few per cent after a year of storage at room temperature (D. Fey, USGS, oral communication, 1999). Many replicate samples have an error of about 10 percent, and a few have a higher error.

These error numbers may be better understood by examination of figure 1 . The error bars show that an analysis for a metal with a concentration of about 10,000 ppb is reliably different from one having $1,000 \mathrm{ppb}$ or $100 \mathrm{ppb}$. Figure 1 shows the magnitude of 5, 10, 20, and 30 percent error bars over a wide range of hypothetical metal compositions. Many of the trace metal determinations (eg. $\mathrm{Cu}, \mathrm{Pb}, \mathrm{Zn}$ ) have error bars like those shown for 10 percent, a few $(\mathrm{Cd})$ may be closer to the 5 percent example, and some (eg. Fe) are like the 20 percent example. This plot shows that even with high analytical error ( 20 or 30 percent) the reported values for about $10,000 \mathrm{ppb}$ do not overlap those of a sample with 1,000 or 100,000. The ICP-MS results are appropriate for comparison of water compositions spanning 4 to 6 orders of magnitude ( 1 to $1,000,000$ ppb). 


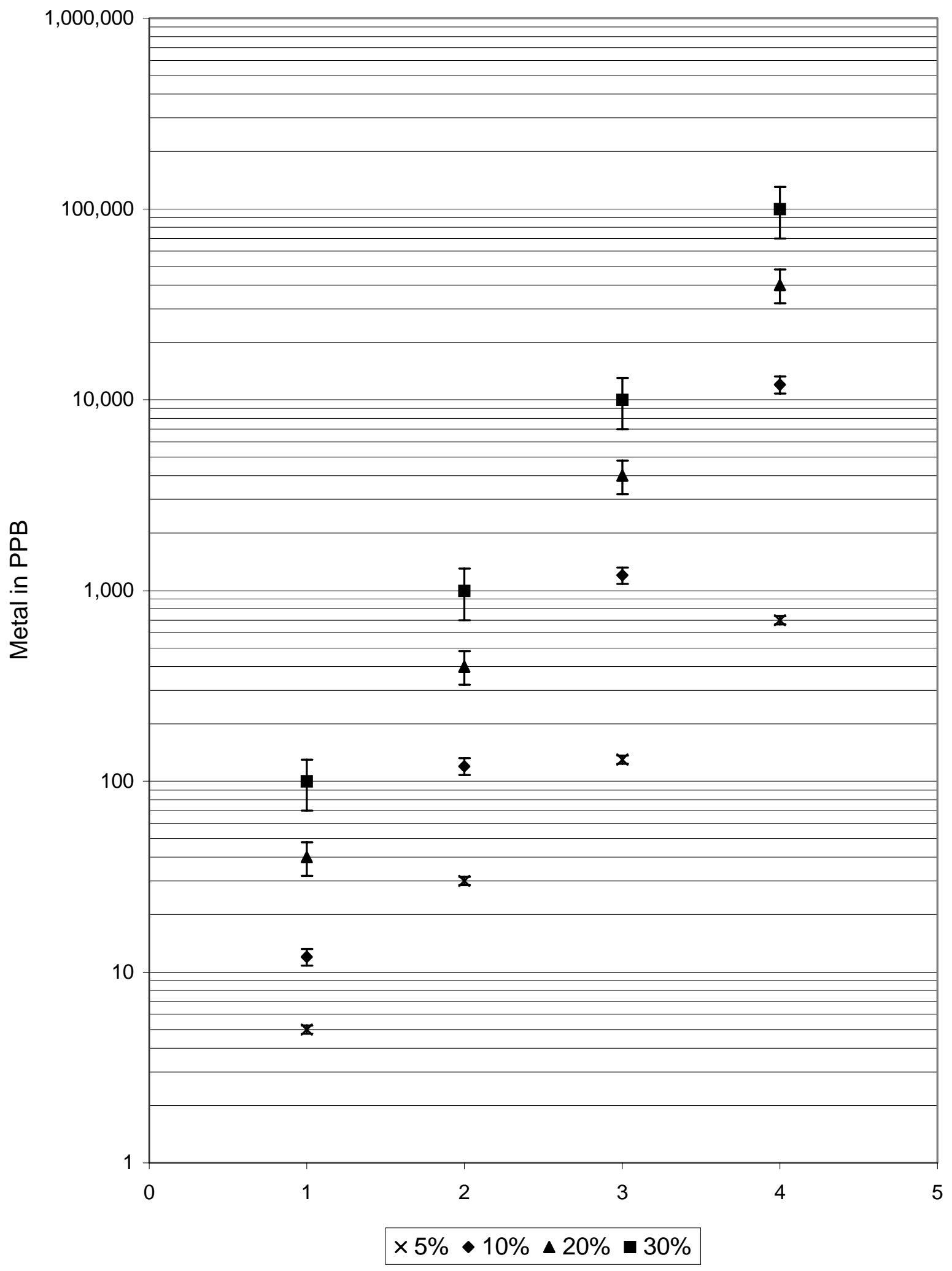

Figure 1: Diagram of analytical error for hypothetical metal concentrations spanning six orders of magnitude. 


\section{REFERENCES CITED}

Briggs, P.H., 1996, Forty elements by inductively coupled plasma-atomic emission spectrometry, in Arbogast, B.F., ed., Analytical methods manual for the Mineral Resource Surveys Program, U.S. Geological Survey Open-File Report 96-525, p. 77-94.

Briggs, P.H., and Meier, A.L., 1999, Determination of forty two elements in geological materials by inductively coupled plasma-mass spectrometry: U.S. Geological Survey Open-File Report 99-166, 15 p.

Crock, J.G., 1996, Mercury, in Methods of Soil Analysis, Part 3, Chemical Methods: Soil Science Society of America, Book Series 5, p. 769-791.

Crock, J.G., Arbogast, B.F., and Lamothe, P.J., 1999, Laboratory methods for the analysis of environmental samples, in Plumlee, G.S., and Logsdon, M.J., eds., The Environmental Geochemistry of Mineral Deposits, Part A.: Society of Economic Geologists, Reviews in Economic Geology, Vol. 6A, p. 265-287.

Curry, J.K., 1996, Total sulfur by combustion, in Arbogast, B.F., ed., Analytical methods manual for the Mineral Resource Surveys Program, U.S. Geological Survey Open-File Report 96-525, p. 106-110.

Fey, D.L., Desborough, G.A., , and Church, S.E., 2000, Comparison of two leach procedures applied to metal-mining related wastes in Colorado and Montana and a relative ranking method for mine wastes, Proceedings Fifth International Conference on Acid Mine Drainage: Denver, Society for Mining, Metallurgical and Exploration, p. 1477-1488.

Ficklin, W.H., and Mosier, E.L., 1999, Field methods for sampling and analysis of environmental samples for unstable and selected stable constituents, in Plumlee, G.S., and Logsdon, M.J., eds., The Environmental Geochemistry of Mineral Deposits, Part A.: Society of Economic Geologists, Reviews in Economic Geology, Vol. 6A, p. 249-264.

Lamothe, P.J., Meier, A.L., and Wilson, Stephen, 1999, The determination of forty four elements in aqueous samples by inductively coupled plasma-mass spectrometry: USGS Open-File Report 99-151, 14 p.

Mee, J. S., Siems, D.F., and Taggart, J. E., 1996, Major element analysis by wavelength dispersive X-ray fluorescence spectroscopy, in Arbogast, B.F., ed., Analytical methods manual for the Mineral Resource Surveys Program, U.S. Geological Survey Open-File Report 96-525, p. 135-142.

Motooka, Jerry, 1990, Organometallic halide extraction applied to the analysis of geologic materials for 10 elements by inductively coupled plasma-atomic emission spectrometry, in Arbogast, B.F., Quality Assurance Manual for the Branch of Geochemistry: U.S. Geological Survey Open-File Report 90-668, p. 92-96.

Nash, J.T., Miller, W.R., McHugh, J.B., and Meier, A.L., 1996, Geochemical characterization of mining districts and mining-related contamination in the Prescott National Forest area, Yavapai County, Arizona: a preliminary assessment of environmental effects: U.S. Geological Survey Open-File Report 96-687, 80 p. 
Nash, J.T., 1999, Geochemical investigations and interim recommendations for priority abandoned mine sites, BLM lands, upper Animas River watershed, San Juan County, Colorado: U.S. Geological Survey Open-File Report 99-323, 45 p.

Nash, J. T., 2000, Hydrogeochemical data for historic mining areas, Humboldt Watershed and adjacent areas, northern Nevada: U. S. Geological Survey Open-File Report $00-459$.

Wandless, G.A., 1996, Instrumental neutron activation analysis by abbreviated count, in Arbogast, B.F., ed., Analytical methods manual for the Mineral Resource Surveys Program, U.S. Geological Survey Open-File Report 96-525, p. 116-123. 